\title{
Extraction and determination of ascorbate and dehydroascorbate from apoplastic fluid of stem of rooted and non-rooted cuttings in relation to the rhizogenesis
}

\author{
Katia Christina Zuffellato-Ribas ${ }^{1 *}$, Stefano Morini $^{2}$, Piero Picciarelli ${ }^{3}$ and Francesco Mignolli ${ }^{3}$ \\ ${ }^{1}$ Departamento de Botânica, Universidade Federal do Paraná, Centro Politécnico, Jardim das Américas, CP 19031, \\ 81531-970, Curitiba-PR, Brasil \\ ${ }^{2}$ Dipartimento di Coltivazione e Difesa delle Specie Legnose, Università di Pisa, Via del Borghetto, 80, 56100, Pisa, Italy \\ ${ }^{3}$ Dipartimento di Biologia delle Piante Agrarie, Università di Pisa, Via Mariscoglio, 34, 56124, Pisa, Italy \\ *Corresponding author: kazu@ufpr.br \\ Received: 11 February 2010; Accepted: 08 June 2010.
}

\begin{abstract}
Starting from semihardwood branches of peach and plum rootstocks (Prunus cerasifera E.) cv. MRS2/5, plum rootstocks (Prunus cerasifera $\times P$. salicina $) \times(P$. cerasifera $\times P$. persica $)$ cv. Ishtarà and olive tree (Olea europaea L.) cv. Frantoio, cuttings were collected and treated with $0 \mathrm{mg.L^{-1 }}$ and $2500 \mathrm{mg} . \mathrm{L}^{-1}$ of indolebutyric acid (IBA) by immersion in the base of the cuttings. After 60 days of planting, the cultivars MRS2/5, Ishtarà and Frantoio presented a significative difference with relation to the rooting induction by application of the indolebutyric acid (27.5, 47.5 and $41.25 \%$, respectively), inducing a higher number of roots per cutting without at the same time significantly increasing the length of the roots themselves. The levels of ascorbate and dehydroascorbate in the rooted and non-rooted cuttings of the three cultivars were determined. These parameters varied in function of the consistency of the cuttings from each species, but showed a positive correlation between the increase of the rooting and the increase of the ascorbate in the reduced form.
\end{abstract}

Key words: olive tree, peach rootstock, plum rootstock, redox potential, rooting.

\section{RESUMO}

A partir de ramos semilenhosos de porta-enxerto de pêssego e ameixa (Prunus cerasifera E.) cv. MRS 2/5, porta-enxerto de ameixa (Prunus cerasifera $\times$ P. salicina) $\times(P$. cerasifera $\times$ P. persica) $\mathrm{cv}$. Ishtarà e oliveira (Olea europaea L.) cv. Frantoio, foram confeccionadas estacas que foram tratadas com 0 mg.L L $^{-1}$ e, $500 \mathrm{mg} . \mathrm{L}^{-1}$ de ácido indol butírico (IBA) por imersão na base das estacas. Após 60 dias de plantio, as cultivares MRS 2/5, Ishtarà e Frantoio apresentaram diferença significativa com relação à indução do enraizamento pela aplicação de ácido indol butírico (27.5, 47.5 e $41.25 \%$, respectivamente), promovendo um maior número de raízes por estaca, sem no entanto aumentar significativamente o comprimento das mesmas. Nas estacas enraizadas das três cultivares, os níveis de ascorbato variaram em decorrência da consistência da estaca de cada espécie, todavia demostram uma correlação positiva entre 0 aumento do enraizamento e 0 aumento dos níveis de ascorbato na forma reduzida.

Palavras-chave: enraizamento, oliveira, potencial redox, porta-enxerto de ameixa, porta-enxerto de pêssego. 


\section{INTRODUCTION}

Great attention has been devoted to the study of biochemical and molecular events during rhizogenesis. These events, grouped in distinct phases (differentiation, induction and growing of roots), so far are poorly characterized at the molecular level, mainly due to the physiological complexity of the process. Some researches identified morphological and biochemichal molecular markers giving a general phisiological condition of the cuttings with relation to rooting capability, and useful for application purposes (Fernandez-Lorenzo et al., 1999; De Klerk et al., 1999).

Cellular redox status is considered an important regulator of cellular metabolism (Sànchez-Fernàndez et al., 1997; Potters et al., 2002). Cytoplasmic equilibrium between the reduced and oxidized forms of ascorbic acid (ASC and DHA) and glutathione (GSH and GSSG) is considered a main factor influencing cellular redox homeostasis. Ascorbic acid and glutathione are known to be involved in the process of detoxification of ROS (reactive oxygen species) and more recently in processes related to plant growth regulation at levels of cell. division and elongation (Potters et al., 2002), typical events in new roots formation.

In the case of ascorbate, different data in literature establish a correlation between the reduced form of ascorbic acid content and growing plant tissues. Diminution of ascorbate content with the aging and differentiation of tissues was observed in tissues and cellular cultures of many different species (De Gara et al., 1993, De Pinto et al., 1999, Potters et al., 2002). In apoplastic fluid of the hypocotyl of Pinus Pinaster, total ascorbate content and the redox status are decreased with ageing of the hypocotyl (Sànchez et al., 1997).

It was recently observed that in the apoplast of etiolated plantlets of pea (Pisum sativum), ascorbate pool (both in reduced and oxidized forms) decreases from meristematic to differentiated zones (De Pinto e De Gara, 2004). Furthermore, in the apoplast, a main part of the ascorbate pool is present in its reduced form. Predominance of oxidized form was observed in the apoplast of plantlets of barley and onion (Vanacker et al., 1998a; Cordoba-Pedregosa et al., 2003a, b; Pignocchi \& Foyer, 2003).

There is an increasing number of evidence demonstrating a direct correlation between the redox status of ascorbate and cellular division process. In Zea mays, the predominant form of ascorbate in the quiescent center of the root apex is the oxidized form. Application of reduced ascorbate in the apoplast stimulates cell division in the quiescent center (Kerk \& Feldman, 1995). It was also observed a relationship between the redox status of the quiescent center and auxins (Jiang et al., 2003). In the quiescent center, beginning of cell division is preceeded by a diminution of IAA levels followed by a change of the redox status of the cells that becomes less oxidized. Kato and Esaka (1999) provided many proofs concerning cell cycle regulation in cell cultures of tobacco, given by ascorbate redox status.

It is known that various factors influence directly the rooting process, such as period of collection of the vegetal material, age of the stock plant, exogenous auxin concentration applied, type of cuttings, presence of leafs and others (Hartmann et al., 2002).

With the intent to verify the cellular redox state through determination of ascorbate and dehydroascorbate in the apoplastic fluid of stem cuttings and its relationship with root induction, three representative species of italian orcharding were studied: olive tree, peach and plum which were exposed to auxin treatment for rooting induction.

\section{MATERIAL AND METHODS}

Plant material: Olive tree (Olea europaea L. - Oleaceae), very common species in regions of Toscana and Umbria, presents more than 395 cultivars documented in the 80's and occupies more than 50.000 hectars of cultivated territory in Italy. The Frantoio cultivar gives an excellent extracted oil quality, medium strength, soft and drooping stems, with medium density of tree crowns, drupe with an average weight slightly bigger than $2 \mathrm{~g}$ and oil yield varying from 17 to $20 \%$ (Fiorino, 2003)

MRS 2/5, natural hybrid of Prunus cersifera E., it's one of the preferred rootstosks for peach and plum trees. It's well adapted to fertile or very fertile grounds, due to its medium strength, presenting a reduced density of tree crown and high quality charachteristics of production (Massai et al., 2003).

Plum Ishtarà rootstocks $(P$. cerasifera $\times P$. salicina $) \times$ ( $P$. cerasifera $x$. persica) is characterized by an intermediate strength and productivity (Gallo et al., 2003), well adapted 
to heavy grounds with root ashpyxia and medium to high percent of active limestone. Planted on fertile soils it reduces the tree size, enhances quality charachteristics of drupes and slightly anticipates maturation season (Foschi \& Ceccaroni, 2004).

Semihardwood stems of peach and plum rootstocks (Prunus cerasifera E.) cv. MRS 2/5, plum rootstocks (P. cerasifera $\times$ P. salicina $) \times(P$. cerasifera $\times$. persica $)$ cv. Ishrtarà, olive tree (Olea europaea L.) cv. Frantoio were collected from stock plants in the Experimental Station of Colignola, under control of Università di Pisa, Facoltà di Agraria, Pisa , Italia, on 09.01.2009 (winter period).

Vegetal material was collected early morning time and taken to Dipartimento di Coltivazione e Difesa delle Specie Legnose "Giovanni Scaramuzzi", Facoltà di Agraria, Università di Pisa, where its preparation was realized. Cuttings were collected from the medium part of the stem and were prepared with about $20 \mathrm{~cm}$ length, $4.5 \pm 0.5 \mathrm{~mm}$ diameter, without leaves for peach and plum rootstocks, and with four complete leaves in the apical portion for olive tree.

Disinfestation was realized by immersion in about 10 $\mathrm{cm}$ of the bottom part of the cuttings in a solution of $3 \mathrm{~g} / \mathrm{L}$ Benlate for $10 \mathrm{~min}$. Afterwards the application of $0 \mathrm{mg}^{-L^{-1}}$ to $2500 \mathrm{mg} \cdot \mathrm{L}^{-1}$ of indolebutyric acid (IBA) was performed by immersion for $10 \mathrm{sec}$ in aproximately $2 \mathrm{~cm}$ in the base of the cuttings with four repeats of 20 cuttings for parcel (160 cuttings for cultivar), that were then planted in boxes of 14 $\times 31 \times 60 \mathrm{~cm}$ (height $\times$ width $\times$ length) which contained perlite as growth media.

The boxes were accomodated on heat controlled benches through an electric resistance, with bottom heat of $20{ }^{\circ} \mathrm{C}$ (basal cutting temperature about $18-20^{\circ} \mathrm{C}$ and apical cutting tempearture of about $16-18{ }^{\circ} \mathrm{C}$ ) inside a greenhouse with intermittent mist (15 sec of spraying every $40 \mathrm{~min}$ ) for cuttings with leaves and without intermitent mist but with a daily irrigation for cuttings without leaves

After 60 days experiments were evaluated, considering the following variables: percentage of rooted cuttings (alive cuttings with at least $1 \mathrm{~mm}$ of lenght), number and length of the roots in the rooted cuttings, percentage of cuttings with callus (alive cuttings presenting callus formation in the base, even with no roots formed), alive (alive cuttings without formation of roots or callus) and dead (cuttings with necrosis).
Data obtained were submitted to variance analysis. Variables those variances showed themselves to be homogeneous around the mean of the treatment were tested by means of the $\mathrm{F}$ Test. When results showed significative differences from the mean of the treatment, variables were compared with test of Tukey at $5 \%$ probability.

Apoplastic fluid extraction: After disinfestation of the vegetal material, samples of approximately $1 \mathrm{~cm}$ of length were removed from the base of each cutting, and properly identified, closed in plastic bags and freezed in liquid nitrogen, being kept into a freezer at $-20{ }^{\circ} \mathrm{C}$ for later realization of the biochemical analysis through extraction and determination of the reduced, oxidized and total ascorbic acid content, from rooted and non-rooted samples of the respective treatment.

Bases of ten cutting samples of each cultivar, with approximately $1.0-1.5 \mathrm{~g}$ of weight, $1 \mathrm{~cm}$ length and $3.0 \pm 1.0$ $\mathrm{mm}$ diameter, that were formerly freezed concurrently with the installation of the experiments, were thawed and infiltrated in $30 \mathrm{ml}$ of acetate buffer, pH 4.5, in vacuum for 2 min (Vanacker et al., 1998b). After delicately drying the cuttings bases from excess of infiltrating solution, they were centrifuged at 4000 rpm for 10 min in a system with two eppendorfs of $1.5 \mathrm{ml}$, one inside the other, being the first, with bases of cuttings inside, previously drilled in its upper and lower part. The system was then accomodated into a corex tube of $30 \mathrm{ml}$. Apoplastic fluid extraction resulted in an extract of about 100 $\mu \mathrm{l}$ for $1 \mathrm{~g}$ of cutting base.

Determination of the reduced, oxidized and total ascorbate: Ascorbate (ASC) and dehydroascorbate (DHA) were determined by Kampfenkel et al. (1995). This analysis is based on the reduction from $\mathrm{Fe}^{3+}$ to $\mathrm{Fe}^{2+}$ of the ascorbic acid (ASC), followed by the spectrofotometric determination of ion $\mathrm{Fe}^{2+}$ complexed with 2,2-dipiridil. Dehydroascorbic acid (DHA) is reduced to ASC through incubation with dithiothreitol (DDT). Excess of DDT is removed wirh N-ethylmaleimide (NEM) and total ASC is determined using 2,2 dipiridil method. Concentration of DHA is calculated by difference between total ASC and ASC (without treatment of DDT).

Total ASC was determined in a reaction mixture of $1.0 \mathrm{ml}$ containing $50 \mu \mathrm{l}$ apoplastic fluid, $100 \mu \mathrm{l}$ phosphate buffer $0.2 \mathrm{M}(\mathrm{pH} 7,4), 50 \mu \mathrm{LDT} 10 \mathrm{mM}$. After shaking and incubation for 20 min at $42{ }^{\circ} \mathrm{C}$ in water bath, $50 \mu \mathrm{l}$ of 0.5 $\%$ NEM were added, with a following incubation for 1 min at 
room temperature. ASC levels were determined in the same way with exception for the increasing of DDT and NEM which were substituted by water. Colouring was obtained by adding of $250 \mu 110 \%$ trichloroacetic acid, $200 \mu$ of $42 \%$ phosphoric acid, $200 \mu \mathrm{l}$ of dipiridil dissolved in $70 \%$ ethanol and $100 \mu \mathrm{l}$ of $3 \%$ phosphoric acid. After shaking, a mixture was incubated for $40 \mathrm{~min}$ at $42^{\circ} \mathrm{C}$ and the absorbance values of the final coloured solutions were recorded at $525 \mathrm{~nm}$ (Kampfenkel et al., 1995).

The results obtained were compared for quantification of ascorbate and dehydroascorbate in rooted and non-rooted cuttings of the studied species. The data obtained were submitted to variance analysis and analized with the same methodology described for the experiment of cutting.

\section{RESULTS}

According to the statistical analysis realized, Prunus cerasifera E. cv. MRS 2/5, $(P$.cerasifera $\times P$. salicina $) \times(P$ .cerasifera $\times P$. persica) $c v$. Ishtarà and Olea europaea $L$. cv. Frantoio presented significative difference with the relation to induction of rooting through the application of indolebutyric acid, which induced a higher number of roots for cutting, without significant increasein their length (Table 1).

Table 1. The effect of indolebutyric acid on peach, plum and olive cuttings: rooted cuttings of peach rootstock (MRS 2/5), plum (Ishtarà) and olive (Frantoio), number of roots per cutting, lenght of the 3 biggest roots per cutting, percentage of cuttings with callus, alive and death cuttings.

$\begin{array}{lllllll}\text { SPECIE } & \text { RC (\%) } & \text { NRC } & \text { LRC (mm) } & \text { CC (\%) } & \text { AC (\%) } & \text { DC (\%) }\end{array}$

Prunus cerasifera E. cv. MRS 2/5

\begin{tabular}{|c|c|c|c|c|c|c|}
\hline Control & $2.50 \mathrm{~b}$ & $1.00 \mathrm{~b}$ & $13.05 \mathrm{a}$ & $45.00 \mathrm{a}$ & $52.50 \mathrm{a}$ & 0 \\
\hline IBA $2500 \mathrm{mg} \cdot \mathrm{L}^{-1}$ & $27.5 \mathrm{a}$ & $36.75 \mathrm{a}$ & $14.76 \mathrm{a}$ & $17.50 \mathrm{a}$ & $55.00 \mathrm{a}$ & 0 \\
\hline \multicolumn{7}{|c|}{$(P$. cerasifera $\times$ P. salicina $) \times(P$. cerasifera $\times P$. persica $)$ cv. Ishtarà } \\
\hline Control & $25.00 \mathrm{~b}$ & $9.25 b$ & $18.33 \mathrm{a}$ & $55.00 \mathrm{a}$ & 25 & 0 \\
\hline IBA $2500 \mathrm{mg}^{-\mathrm{L}^{-1}}$ & $47.50 \mathrm{a}$ & $46.75 \mathrm{a}$ & $22.74 \mathrm{a}$ & $52.50 \mathrm{a}$ & 0 & 0 \\
\hline \multicolumn{7}{|c|}{ Olea europaea L. cv. Frantoio } \\
\hline Control & $5.00 \mathrm{~b}$ & $2.75 b$ & $16.33 \mathrm{a}$ & $57.50 \mathrm{a}$ & $32.50 \mathrm{a}$ & $5.00 \mathrm{a}$ \\
\hline IBA $2500 \mathrm{mg} \cdot \mathrm{L}^{-1}$ & $41.25 \mathrm{a}$ & $38.00 \mathrm{a}$ & $20.38 \mathrm{a}$ & $32.50 \mathrm{~b}$ & $25.00 \mathrm{a}$ & $1.25 \mathrm{a}$ \\
\hline
\end{tabular}

Means followed by the same letter in the rows, for each cultivar, do not differ by Tukey's test at $5 \%$ probability. Abbreviations used: RC, rooted cuttings; NRC, number of roots per cutting; LCR, lenght of roots per cutting; CC, cuttings with callus (CC); AC, alive cutting; DC, death cuttings; IBA, indolebutyric acid.

Formation of callus was observed in all species studied, showing statistic differences only in the olive cuttings, in which control presented the higher values. The high percentage of callus formation added to the high survival rate of cuttings that did not root suggest that if the vegetal material would be left for a longer time in the greenhouse it could possibly develop roots, since death rate was virtually null.

Figure 1 summarizes the results of the quantification of ascorbate and dehydroascorbate in rooted and nonrooted cuttings subjected to control and IBA treatments. In the Istarà genotype, levels of ascorbate in rooted cuttings of the control group and of the group treated with IBA, did not present a statistical difference, showing themselves to be higher than comparing tothe values detected in the nonrooted cuttings treated with IBA and non-rooted control, that presented significative differences among them. The higher presence of ascorbate in these cuttings probably induced a higher rhizogenesis, while in the non-rooted cuttings the levels of ascorbate were lower independently from the auxinic treatment. 
FROM APOPLASTIC FLUID OF STEM OF ROOTED AND NON-ROOTED CUTTINGS IN RELATION TO THE RHIZOGENESIS
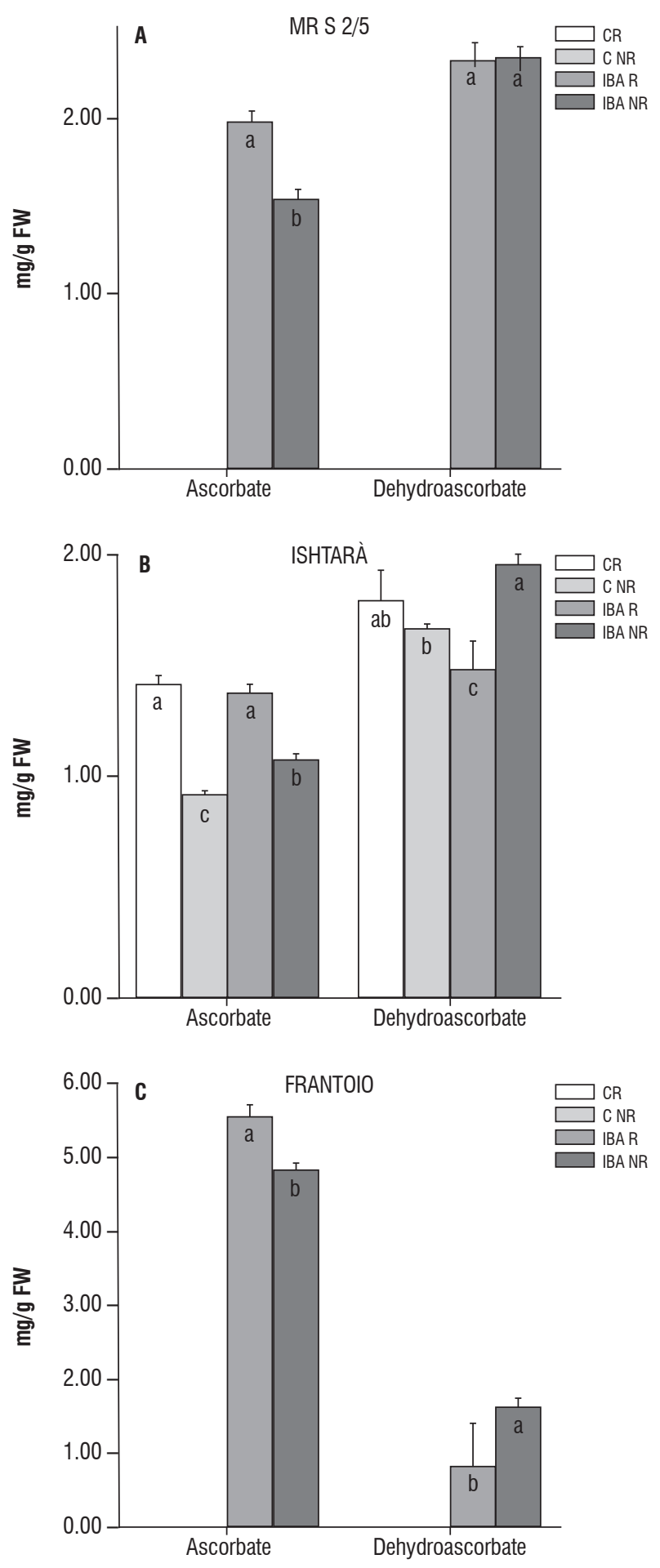

Figure 1. Quantification of ascorbate and dehydroascorbate levels in rooted and non-rooted cuttings of (A) peach rootstocks (MRS 2/5), (B) plum (Ishtarà) and (C) olive tree (Frantoio). Averages followed by the same minor letter, in the ascorbate and dehydroascorbate columns, respectively, do not differ significantly among them both for Turkey test at $5 \%$ of probability. Abbreviations used: CR, rooted control; CNR: non-rooted control; IBA R: rooted + IBA; IBA NR: non-rooted + IBA; IBA, indolebutyric acid.
Apoplastic fluid extraction performed with the cuttings treated with IBA revealed that the non-rooted samples presented notably higher values of dehydroscorbate than the rooted ones, and these differed also with relation to the nonrooted control cuttings.

Cultivars MRS 2/5 and Frantoio presented the same behaviour with relation to the levels of endogenous ascorbate in the cuttings, determined at the moment of the experiment installation in the greenhouse. The levels of reduced ascorbate were significantly increased in cuttings rooted and treated with IBA when compared to non-rooted cuttings and treated with IBA as well. This fact points out that higher rhizogenesis potencial is bound to endogenous levels of ascorbate at the moment of the vegetal material collection. Determination of ascorbate and dehydroscrobate in control treatment was not realized due to absence of rooting.

For both rooted and non-rooted cuttings of MRS 2/5 rootstocks, the levels of dehydroscorbate did not present significative differences. Notable, the levels of dehydroscorbate were considerably higher in non-rooted cuttings when compared to rooted ones for the olive tree cv. Frantoio cuttings treated with IBA.

\section{DISCUSSION}

The positive effect of indolebutyric acid on rhizogenesis was observed in several wooden species. Pio et al. (2005) obtained a greater rooting in cuttings of olive cv. Grapollo (45.81\%) and a bigger number of roots per cutting through the application of $2000 \mathrm{mg} \cdot \mathrm{L}^{-1} \mathrm{IBA}$, confirming the ideal concentration for the Olea europaea rooting. For the cultivar Coratina, Raham et al. (2002) found the major indexes of rooting after the application of $3000 \mathrm{mg} \cdot \mathrm{L}^{-1} \mathrm{IBA}(80 \%)$ and incubation for 90 days in greenhouse.

Rhizogenesis is a process that is strictly related to the species and cultivars studied, presenting alterations depending on the endogenous state of the stock plant donor of seedlings. Due to this fact different percentages of rooting are found regarding on species and cultivars studied. What is claimed in this type of study is to verify the inductive action of the IBA for each specific case, with the intent to obtain long term reproducible results. 
Sebastiani and Tognetti (2004) reported that in evaluations performed on Oliveira cv. Frantoio cuttings after 57 and 88 days in greenhouse, significative modifications of the response frequency are observed, being the better rooting resulted from application of $4000 \mathrm{mg} . \mathrm{L}^{-1} \mathrm{IBA}$. The same authors observed differences of long term response on different years of experiment, that is, percentage of rooting is alterated in virtue of the environmental conditions under which the stock plant was submitted.

As it is well known that rhizogenesis is a process strictly related to species, to age of the stock plant, to endogenous concentration of auxin, to period of the year of the material collection and to other factors. With relation to the rooting response of rootstocks of peach cvs. Ishtarà, Mirabolano 29C, Pixy and Myran, Stanica (2007) observed that the percentage of rooting and quality of roots formed was strongly influenced by the auxinic treatment utilized (naphtalenic acetic acid at $3000 \mathrm{mg} \cdot \mathrm{L}^{-1}$ ), by the species and cultivars utilized and also by the type of growth media. Also for the peach tree (Prunus salicina), different cultivars and period of collection may present different responses of rooting. Kersten et al. (1993) found that for cv. Carmesin the rooting was more effective than that one for cv. Grancuore, and that autumn and winter are the most favorable periods for the vegetal material collection.

Considering that the present study was carried out only in one period of the year (winter), different results may have been obtained if they were repeated in spring, winter and autumn. In the meanwhile, the basic intention of this research was to compare results of rooting obtained in a determined period with quantification of reduced and oxidized ascorbate in the cuttings, and correlateits relationship with the rooting induction.

Sorce et al. (2004) determined the content of ascorbate pool forms (reduced and oxydized), in the apoplastic fluid of extracts of the basal portions (almost $1 \mathrm{~cm}$ lenght) of cypress cuttings (Cupressus sempervirens) collected before planting into the rooting benches, and observed a strict correlation between the presence of the reduced form of ascorbate in the cuttings' tissues with the formation of adventitious roots. In all the cuttings that rooted the relationship between the reduced and the oxidized forms of ascorbate was clearly in favour of the former while in the non-rooted cuttings the relationship was in favour of the oxidized forms, together with a significative reduction in the total ascorbate content.

Using the same methodology described in the present work, Tyburski et al. (2006) determined the levels of ascorbate and dehydroascorbate during the rooting of small cuttings of tomato (Lycopersicon esculentum Mill. cv. Paw) and verified that the first three days in a Murashige Skoog (1962) medium were accompained by a rapid increase of the ascorbic acid in the rooting areas. After this period the authors observed a dramatic decrease of ascorbate levels indicating its importancefor the cell division, elongation and root formation. Given that some of the effects of ascorbate are the stimulation of root formation in a cutting and a reduction of their length, this substance might be considered similar to the exogenous auxine.

According to these informations, Pignocchi and Foyer (2003) suggested that the oxidation of apoplast due to oxidation of ascorbic acid to dehydroascorbate results in significative cell mutations, from which the attenuation of the growing signal for transduction processes are basicly holding by auxins and giberelins.

In the present study, independently of the studied species, in the rooted cuttings, the higher levels of reduced ascorbic acid at the time of collection of the vegetal material were related to a greater rooting potential.

\section{CONCLUSIONS}

The exposure of the cuttings of rootstocks of peach and plum cv. MRS 2/5, rootstocks of plum cv. Ishtarà and olive tree cv. Frantoio to indolebutyric acid induced rhyzogenesis; a positive correlation between the stimulation of rooting and the increase of reduced ascorbate levels was established.

Acknowledegements: The authors are grateful to CNPq for a post-doc scholarship to K.C.Z-R., Grazia Fiaschi and Fausta Rocco for the helpful in the greenhouse, Marco Grassi for the translation of this work and anonymous reviewer for the helpful comments. 


\section{REFERENCES}

Córdoba-Pedregosa MC, Córdoba F, Villalba JM, Gonzáles-Reyes JA (2003a) Zonal changes in ascorbate and hydrogen peroxide contents, peroxidase, and ascorbate-related enzymes activities in onion roots. Plant Physiol. 131:1-10.

Córdoba-Pedregosa MC, Córdoba F, Villalba JM, Gonzáles-Reyes JA (2003b) Differential distribution of ascorbic acid, peroxidase activity, and hydrogen peroxide along the root axis in Allium cepa L. and its possible relationship with cell growth and differentiation. Protoplasma. 221:57-65.

De Gara L, Paciolla C. Liso R, Stefani A, Blanco A, Arrigoni 0 (1993) Ascorbate metabolism in mature pollen grains of Dasypyrum villosum. J. Plant Physiol. 141:405-409.

De Klerk GJ, Van der Krieken W, De Jong J (1999) Review - The formation of adventitious roots: new concepts, new possibilities. In Vitro Cell. Dev. Biol. Plant. 35:189-199.

De Pinto MC, De Gara $L$ (2004) Changes in the ascorbate metabolism of apoplastic and symplastic spaces are associated with cell differentiation. J. Exp. Bot. 55:2559-2569.

De Pinto MC, Francis D, De Gara $L$ (1999) The redox state of the ascorbatedehydroascorbate pair as a specific sensor of cell division in tobacco BY-2 cells. Protoplasma. 209:90-97.

Fernandez-Lorenzo JL, Rigueiro A, Ballester A (1999) Polyphenols as potential markers to differentiate juvenile and mature chestnut shoot cultures. Tree Physiol. 19:461-466.

Fiorino P (2003) Olea: trattato di olivicoltura. Edagricole: Bologna.

Foschi S, Ceccaroni S (2004) Pesco: come contrastare la "stanchezza" del terreno. In Azienda / Studi \& Ricerche. Agricoltura, ottobre, pp, 119-121.

Gallo P, Longo L, Spagnolo G, Massai R (2003) Valutazione dei portinnesti del pesco nella Media Valle del Crati: risultati del progetto MI. P. A. F. IV Convegno Nazionale sulla Peschicoltura Meridionale. Campobello di Licata ed Agrigento, 11 e 12 settembre (http://unipa.it/medpeach/atti/)

Hartmann H, Kester DE, Davies FE, Geneve R (2002) Plant propagation: principles and practices. 7 ed. New York: Englewood Cliffs.

Jiang K, Meng YL, Feldman LJ (2003) Quiescent center formation in maize roots is associated with an auxin-regulated oxidizing environment. Development. 130:1429-1438.

Kampfenkel K, Van Montagu M, Inzé D (1995) Extraction and determination of ascorbate and dehydroascorbate from plant tissue. Anal. Biochem. 225:165167.

Kato N, Esaka M (1999) Changes in ascorbate oxidase gene expression and ascorbate levels in cell division and cell elongation in tobacco cells. Physiol. Plant. 105:321-329.

Kerk NM, Feldman LJ (1995) A biochemical model for the initiation and maintenance of the quiescent center: implications for the organization of root meristems. Development. 121:2825-2833.
Kersten E, Lucchesi AA, Gutierrez LE (1993) Efeito do ácido indolbutírico no enraizamento de estacas de ramos e plants de ameixeira (Prunus salicina, Lindl.). Sci. Agric. 50(1):19-26.

Massai R, Loreti F, Caruso T (2003) I portinnesti per aree peschicole caldoaride del mezzogiorno d'Italia. IV Convegno Nazionale sulla Peschicoltura Meridionale. Campobello di Licata ed Agrigento, 11 e 12 settembre (http:// unipa.it/medpeach/atti/)

Murashige T, Skoog F (1962) A revised medium for rapid growth and bioassays with tobacco tissue culture. Physiol. Plant. 15:437-497.

Pignocchi C, Foyer CH (2003) Apoplastic ascorbate metabolism and its role in the regulation of cell signalling. COPLBI. 6:379-389.

Pio R, Bastos DC, Berti AJ, Scarpe Filho JA, Mourão Filho FAA. Entelmenn FA, Alves ASR, Bettiol Neto JE (2005) Enraizamento de diferentes tipos de estacas de oliveira (Olea europaea L.) utilizando ácido indolbutírico. Ciênc. agrotec. 29(3):562-567.

Potters G, De Gara L, Asard H, Horemans N (2002) Ascorbate and glutathione: guardians of cell cycle, partners in crime? Plant Physiol. Biochem. 40:537548.

Rahman N, Awan AA, Nabi G, Ali Z (2002) Root initiation in hard wood cuttings of olive cultivar Coratina using different concentration of IBA. Asian J. Plant Sci. 1(5):563-564.

Sànchez M, Queijeiro E, Revilla G, Zarra I (1997) Changes in ascorbic acid levels in apoplastic fluid during growth of pine hypocotyls. Effect on peroxidase activities associated with cell walls. Physiol. Plant. 101:815-820.

Sànchez-Fernàndez R, Friker M, Corben LB, White NS, Sheard N, Leaver CJ, Van Montagu M, Inzè D, May MJ (1997) Cell proliferation and hair tip growth in the Arabidopsis root are under mechanistically different forms of redox control. Proc Nat AcadSci USA, 94: 2745-2750.

Sebastiani L, Tognetti R (2004) Growing season and hydrogen peroxide effects on root induction and development in Olea europaea L. (cvs "Frantoio" and 'Gentile di Larino') cuttings. Sci. Hortic. 100:75-82.

Sorce C, Paolicchi F, Ceccarelli N, Lorenzi R, Picciarelli P (2004) Relation between cell redox status and adventitious rooting in cuttings of Cupressus sempervirens. Proceedings of SIFV-SIGA Joint Congress.

Stanica F (2007) Propagation of Prunus rootstocks by hardwood cuttings on composed rooting substrates. Acta Horticulturae (ISHS), VIII International Symposium on Plum and Prune Genetics, Breeding and Pomology, 734:309-311.

Tyburski J, Jasionwicz P, Tretyn A (2006) The effects of ascorbate on root regeneration in seedling cuttings of tomato. Plant Growth Regul. 48:157-173.

Vanacker H, Carver TLW, Foyer CH (1998a) Pathogen-induced changes in the antioxidant status of the apoplast in barley leaves. Plant Physiol. 117:11031114.

Vanacker H, Ruisch JH, Carver TLW, Foyer CH (1998b) Antioxidant defences of the apoplast. Protoplasma. 205:129-140. 